\title{
THE PLACENTAL BARRIER OF Kerodon rupestris (Rodentia: Caviidae)
}

\section{A BARREIRA PLACENTÁRIA DO MOCÓ, Kerodon rupestris (Rodentia: Caviidae)}

\author{
Moacir Franco de OLIVEIRA ${ }^{1}$; Gleidson Benevides de OLIVEIRA ${ }^{2}$; \\ Ferdinando Vinícius Fernandes BEZERRA ${ }^{2}$; Felipe Venceslau CÂMARA ${ }^{2}$; \\ Alexsandra Fernandes PEREIRA ${ }^{1}$; Alexandre Rodrigues SILVA ${ }^{1}$; Maria Angélica MIGLINO ${ }^{3}$ \\ 1. Professor, Doutor, Departamento de Ciências Animais, Universidade Federal Rural do Semi-Árido, Mossoró, RN, Brasil. \\ moacir@ufersa.edu.br; 2. Doutorando em Ciência Animal, Departamento de Ciências Animais, Universidade Federal Rural do \\ Semi-Árido, Mossoró, RN, Brasil; 3. Professor, Doutor, Departamento de Cirurgia, Faculdade de Medicina Veterinária e \\ Zootecnia da Universidade de São Paulo, São Paulo, SP, Brasil.
}

\begin{abstract}
The placenta of the rodents generally has a chorial-allantoic, discoid and hemochorial shape. Since they resemble the process of human placentation, such characteristics make this order an interesting experimental model for understanding placentation, placental barrier and the physiological mechanisms involved in maternal-fetal exchanges. Due to the fact that Kerodon rupestris may be used as placental model, current analysis characterizes the rodent's placental barrier ultrastructure. Current assay used three and two placentas, obtained from the Centro de Multiplicação de Animais Silvestres da Universidade Federal Rural do Semi-Árido (CEMAS/UFERSA) in Mossoró RN Brazil, respectively at the mid-third period of pregnancy and at the final third period of pregnancy. Samples, measuring approximately $1.0 \mathrm{~cm}$, were collected and fixed in paraformaldehyde solution in a phosphate buffer $0.1 \mathrm{M}, \mathrm{pH} 7.4$, at $4{ }^{\circ} \mathrm{C}$, while $0.5 \mathrm{~mm}^{2}$ fragments were fixed in glutaraldehyde solution $2.5 \%$, buffered with sodium phosphate at $0.1 \mathrm{M}$, $\mathrm{pH} 7.4$, and analyzed, respectively, under light and electron transmission microscope. The Kerodon rupestris's placenta had a discoid form and resulted from the interaction between the chorion and the allantois. It was thus classified as a model chorioallantoic placenta which, macro and microscopically, consisted of lobes predominantly made up of fetal capillaries that interposed mostly in gaps or maternal spaces. The inter-hematic space or maternal-fetal barrier placenta of K. rupestris is composed of three distinct elements represented by the fetal capillary wall, basement membrane and a single layer of trophoblast cells of a syncytial nature or strictly syncytiotrophoblast, which separate maternal from fetal blood, and at the same time is the medium through which all metabolic exchange between mother and fetus are processed. These characteristics are typical of hemochorial placentas. Since the barrier contains a single syncytiotrophoblast layer, it is classified within the hemomonochorial subtype, a behavior similar to that reported in hystricomorph rodents such as the agouti, paca, capybara and cavy.
\end{abstract}

KEYWORDS: Animal model. Hemochorial placenta. Kerodon rupestris. Placenta. Rodents.

\section{INTRODUCTION}

Rodentia is the largest order among the Eutheria and these animals feature great ecological adaptation and physiological abilities, enduring several types of climates and altitudes through diverse adaptations (QUEIROZ et al., 2011). The rodents, restricted to the Brazilian northeastern region, belong to the Caviidae family, Caviinae subfamily (ADRIAN; SACHSER, 2011; RODRIGUES et al., 2013; OLIVEIRA et al., 2014) and genus Kerodon (THOMAZ et al., 2006). They lack clavicles but have elongated jaws on which teeth are distributed in a characteristic manner when compared to that of other types of rodents. The dorsal surface has a light grey color mixed with black and white, whereas the back section of the tights is of a brown-reddish color. They are gregarious with twilight habits, spending the day sheltering in rocks holes, leaving in the evening and at dawn to feed on branches of trees and shrubs (OLIVEIRA et al., 2011; RODRIGUES et al.,
2013). They have a short gestation period, averaging 65 days, calving one to two pups per litter (PINHEIRO et al., 1989).

According to Abrahamsohn and Zorn (1993), success in viviparity in mammals depends on the association between maternal and fetal tissues for an adequate interchange between the mother's and the fetus's organism. Implantation is the first step to establish this association. The interaction results in a transitory organ which is typical of pregnant mammal females, or rather, the placenta which is a structure with morphofunctional characteristics distinct to each mammal group (PIJNENBORG et al., 1981). Such variability comprises the type and number of membranes involved and their contact with the uterus, the organ's external shape, the geometrical model of interdigitation of the maternal and fetal surfaces, the type and number of tissue layers separating the maternal and fetal blood and the geometrical arrangement of maternal and fetal capillary 
exchanges which determine their nutritional flux (BROLIO et al., 2010).

As a rule, rodents have a chorium-allantois, discoid and hemochorial type of placenta since the maternal and fetal interaction is the result of the invasion of uterine vascular milk through the trophoblast, which is bathed by overflowing maternal milk (MOSSMAN, 1937, 1987; SCHLAFKE; ENDERS, 1975; WELSH; ENDERS, 1991). Due to the fact that the above placental characteristics are similar to human placenta and to the placentation process and due to biological characteristics such as animal size, low maintenance costs, short pregnancy period and many offspring, the animal order under analysis constitutes an interesting experimental model to understand placentation, placental barrier and physiological mechanisms involved in maternal-fetal exchanges. Since there is a scarcity of data on the placentation of $K$. ruprestris in the literature, current investigation deals with the placental barrier of the species as a supplement to previous publications (OLIVEIRA et al., 2001; MIGLINO et al., 2004; ZOGNO et al., 2004; OLIVEIRA et al., 2006; RODRIGUES et al., 2013; OLIVEIRA et al., 2014).

\section{MATERIAL AND METHODS}

Five females of Kerodon rupestris, three at the mid-third period and two at the final third period of pregnancy, were obtained from the Center for the Multiplication of Wild Animals (CEMAS/UFERSA), a scientific breeding complex registered at IBAMA (n. 1478912) in Mossoró, RN, Brazil. The material was harvested from females submitted to pre-anesthetic procedures with ketamine hydrochloride $(15 \mathrm{mg} / \mathrm{kg})$ and midazolam $(1 \mathrm{mg} / \mathrm{kg})$ by intramuscular injection; after fifteen minutes, induction and maintenance under mask with oxygen $100 \%$ associated with isoflurane. When anesthetized, a median longitudinal incision was made to expose the pregnant uterus; the pregnant horn was removed and the placenta and other fetal annexes were described.

Fragments with mean $1 \mathrm{~cm}$ diameter and fixed in paraformaldehyde solution in a phosphate buffer at $0.1 \mathrm{M}, \mathrm{pH} 7.4$ and $4^{\circ} \mathrm{C}$ were analyzed under a light microscope. After being fixed, the material was dehydrated with increasing ethanol concentrations, diaphanized in xylol and soaked in histological paraffin (Paraplast). Further, $5 \mu \mathrm{m}$ cuts were made by a microtome (Leica MR 2065) and the laminas stained with hematoxylin-eosin, following methodology by Tolosa et al. (2003).
Fragments with approximately $0.5 \mathrm{~mm}^{2}$ were removed from the labyrinth and interlobular regions for the ultrastructure characterization of the cavies' placenta, so that the type of placental barrier could be defined, following method by Enders (1965). Fragments were immersed in a glutaraldehyde solution $2.5 \%$ and buffered with sodium phosphate at $0.1 \mathrm{M}, \mathrm{pH}$ 7.4. After being fixed, the material was processed and included in araldite (Araldite 502 - Polysciences). When polymerization was finished, semi-thin $0.4 \mu$ n-cuts were performed by automatic ultramicrotome (LEICA ULTRACUT R), hot-stained with toluidine blue water solution $1 \%$ and analyzed under a light microscope (LEICA RM 2065) to identify interesting regions for ultrafine cuts and to photograph under a light microscope. When the 0.07 $\mu \mathrm{m}$-thick cuts were processed, they were analyzed under an electron transmission microscope (JEOL 100-CXII) and regions under analysis were electrophotomicrographed.

\section{RESULTS}

The discoid-shaped placenta of the K. rupestris results from the chorium-allantois interaction. When sectioned longitudinally or transversally, an area corresponding to placental lobules and interlobules was revealed. Syncytiotrophoblast cells in the labyrinth were observed under a microscope, featuring very near nuclei (Figure 1A and B) and well-organized nucleoli lying peripherally to the chorium membrane (Figure 1C). The syncytium cytoplasm had a large number of vesicles with low electrodensity, featuring a vacuolated aspect.

The placenta of the K. rupestris is rich in maternal lacunae identified in the interlobular and labyrinth region (Figure 1A). In fact, they are sites where maternal-fetal exchanges normally occur through the placental barrier; they are also the site for blood return to the maternal organism. Maternal blood canals, probably to blood return, were detected in the sub-placental and marginal syncytium region (Figure 2B).

The maternal-fetal barrier of the $\mathrm{K}$. rupestris' placenta was constructed by a single layer of syncytium trophoblast cells and by the endothelial wall of the fetal capillary separated by the basal membrane. The species's placenta and the placental barrier could be defined as hemochorial type and hemomonochorial subtype (Figure 2A and $3)$.

The regions with the syncytiotrophoblast, a site where the barrier was thinner, had a large 
number of cytoplasm vesicles. Moreover, the surface, throughout the barrier, bathed by maternal blood, was rich in microvillosity with numberless vesicles at the edges, immersed in maternal blood in the lacunae (Figure 3A and B). They are actually areas in which maternal and fetal exchanges occur through the placental barrier or represent sites of blood returned to the maternal organism which may be identified in the placental labyrinth and interlobular region.

Maternal lacunae, identified in the subplacental region, were limited by syncytium cells on one side; on the other side, they were limited by cytotrophoblasts in contact with maternal blood, containing the microvillosities, and behaving as in the placental labyrinth (Figure 2B). However, syncytiotrophoblast was the component in contact with maternal blood in all regions in which maternal lacunae were reported. It should be underscored that the fetal capillaries related to these canals in the sub-placenta were hypertrophied nuclei and that the cytoplasm of the endothelial cells emitted projections towards the light of the vessels in the sub-placenta (Figure 2D). The blood canals in the marginal syncytium region on the surface of the placenta facing the fetus revealed gigantic trophoblast cells forming its wall and replacing the syncytiotrophoblast, together with the two cell elements (Figure 2C). Gigantic trophoblast cells (Figure 3C) provided a greater cytoplasm when compared to the cytoplasm of the normal syncytium cells.

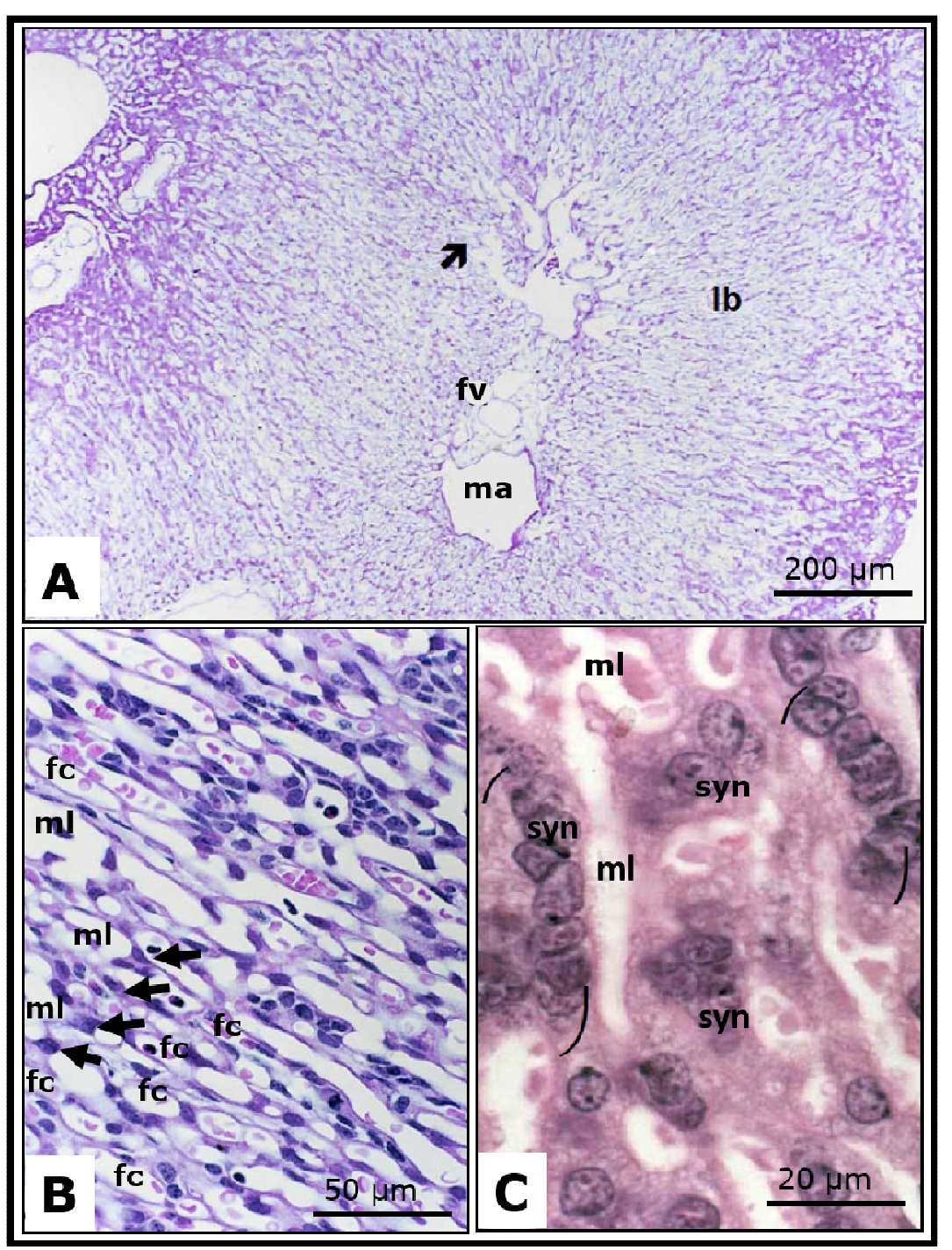

Figura 1. Photomicrography of placental lobule (lb) of the $K$. rupestris' placenta. (A) shows the maternal artery (ma), the fetal vein (fv) and maternal lacuna (arrow) in the center of the lobule. (B) shows the organization of the capillaries (fc) in parallel and syncytiotrophoblast (arrow) involving the maternal lacuna $(\mathrm{ml})$ and separating the fetal blood from the maternal one. (C) underscores proximity between the nuclei of the syncytiotrophoblast cells (syn) involving a maternal lacuna (ml). Paraplast, $5 \mu \mathrm{m}$, hematoxylin-eosin. 

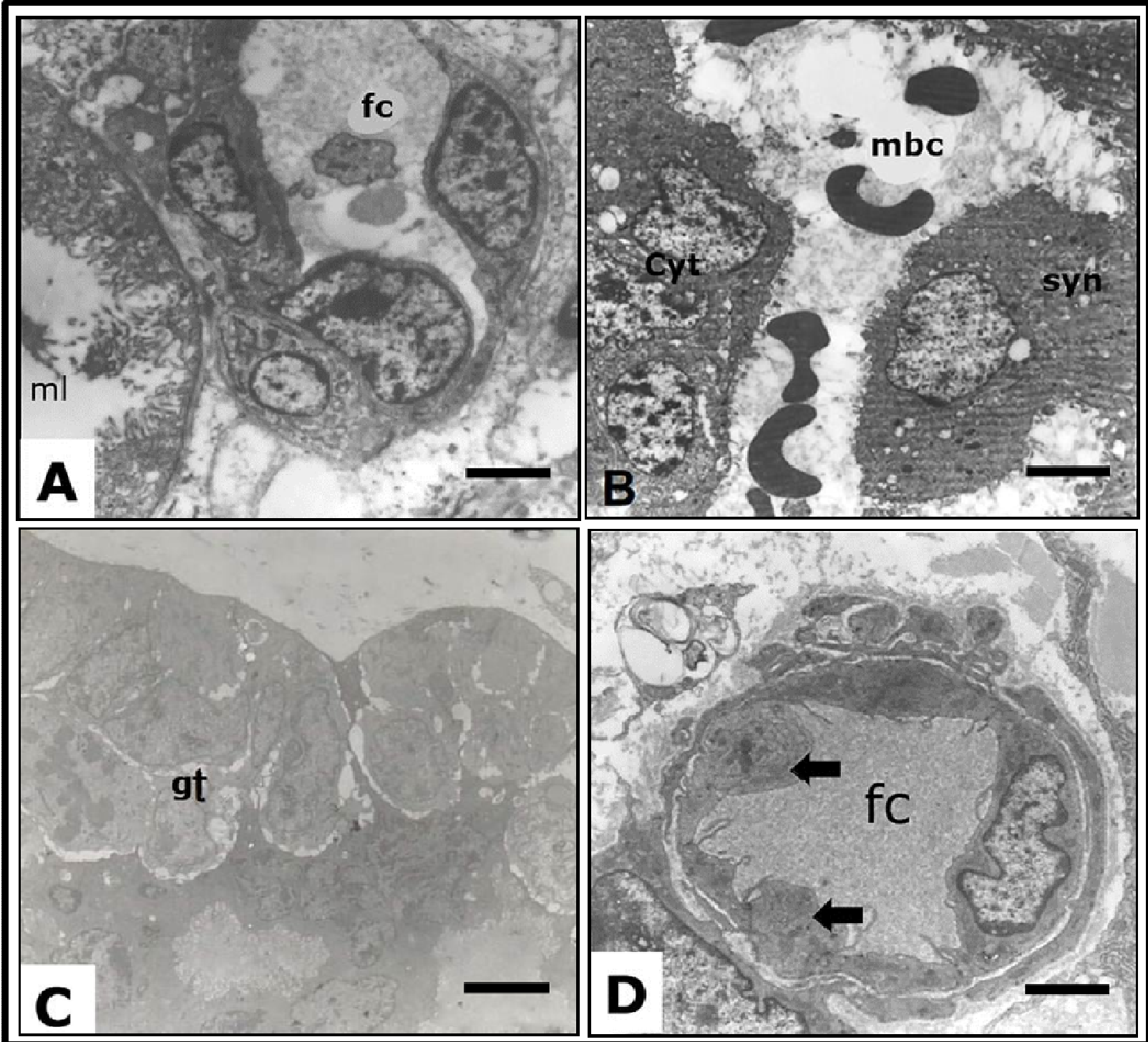

Figure 2. Electromicrograph of the placental barrier of the K. rupestris' placenta. (A) shows the placental barrier in the placental labyrinth characterized by the fetal capillary (fc) and maternal lacuna (ml). In (B) and (C), maternal blood canals (mbc), respectively in the sub-placenta and in the marginal syncytium. One may observe cell (cyt) and syncytium trophoblast (cyt) forming the blood canal in the sub-placenta and the gigantic trophoblast (gt) limiting the blood canals in the marginal syncytium region. (D) details the projections of endothelial cell cytoplasm (arrows) in the light of fetal capillary (fc). Araldite, $70 \mathrm{~nm}$, uranyl acetate and lead citrate. A- $59.6 \mu \mathrm{m}$; B- $18.8 \mu \mathrm{m}$; C$18.8 \mu \mathrm{m}$; D- $59.6 \mu \mathrm{m}$. 


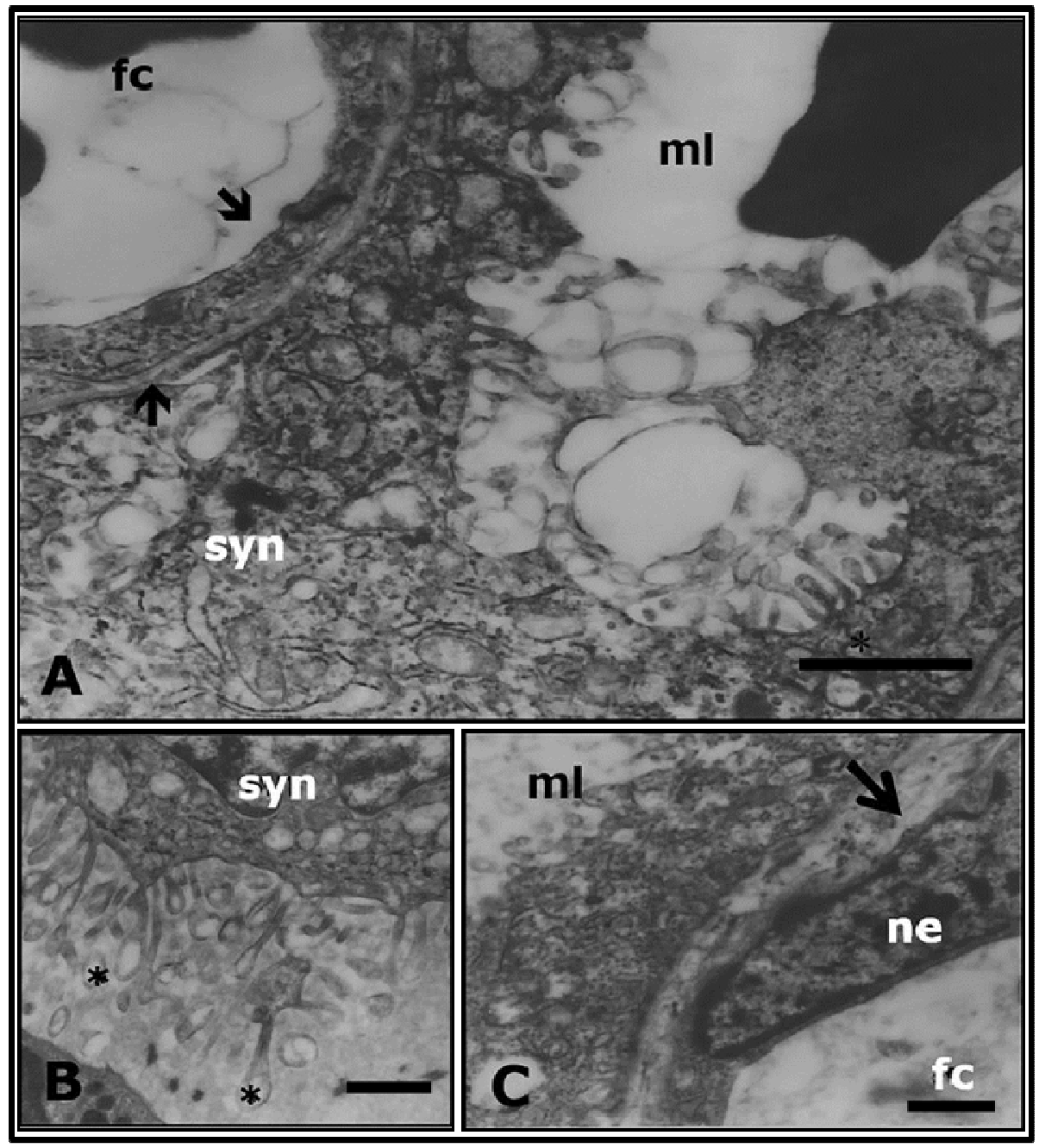

Figure 3. Electromicrograph of the placental barrier of the K. rupestris' placenta. (A) shows the endothelium of the fetal capillary $(\mathbf{V})$ and the single layer of syncytiotrophoblast (syn) separated by the basal membrane basal $(\boldsymbol{\uparrow})$. Syncytium cytoplasm $(\sin )$, rich in organelles and microvillosity $(*)$, facing the maternal lacuna (ml) may be observed. (B) details microvillosities (*) of syncytiotrophoblast (syn) bathed in maternal blood. (C) shows nucleus of the endothelial cell (ne) of the fetal capillary (fc) and the basal membrane with an amorphic aspect (arrow) followed by syncytiotrophoblast (syn). Araldite, $70 \mathrm{~nm}$, uranyl acetate and lead citrate, A- $243 \mu \mathrm{m}$; B- $135 \mu \mathrm{m}$; C- $128 \mu \mathrm{m}$.

\section{DISCUSSION}

From the morphological and functional stand point, the placenta is a complex organ, defined as the functional center of the maternal-fetal biological unit. It undergoes macroscopic and microscopic modifications in its structure during development which reveals the maturation process (Mossman, 1987).

The pregnant placenta in $K$. rupestris presents macroscopically a discoid geometry, resulting from the chorium-allantois interaction. It is thus a chorioallantoic placenta, similar to that described by Leiser and Kaufmann (1994). It should be emphasized that that rodents' placenta tends to have a discoid shape, similarly to the $K$. rupestris, even though other species do not. Mossman (1937, 1987) describes the discoid shape of the placenta in several rodent families even though the same author and Rodrigues et al. (2003) described the placenta of the Dasyprocta aguti as sphere-shaped. Mossman (1937, 1987) and Rodrigues et al. (2003) mention a thin mesoplacenta in this rodent, albeit not detected in the $K$. rupestris.

Researchers not only agree that rodents' placenta is discoid-shaped, but that the placenta of hystricomorph rodents is composed of lobules. The fact has already been established at the time that researchers described the macroscopic characteristics of the placenta, as may be surmised in several studies. Kanashiro et al. (2009) studied the placentas of Hydrochaeris hydrochaeris, Ferreira et al. (2001) the placentas of Myocastor coypus, and Kaufmann (1981) the placentas of 
The placental barrier...

Cavia porcellus at the end of pregnancy. They all reported a lobed and discoid placenta in these species. Bonatelli et al. (2005) classified the placenta of Agouti paca as discoid and lobed; similarly Oliveira et al. (2006) in their studies on the placenta of the $K$. rupestris. Oliveira et al. (2012) studied the placentation of the rodent Trichomys laurentinus and described the placenta as discoid and heavily lobed, as from mid-pregnancy till birth, similar to that of $K$. rupestris. Referring to the macroscopic characteristics of the placenta, researchers describe it as structurally lobed, very similar to Graça-Pires (1998) and Mossman (1926) who studied the placenta of Oryctolagus cuniculus and classified it as bi-discoid and bi-lobed, although currently these animals are classified as belonging to the Lagomorpha order. The exception mentioned by Mossman and Weisfeldt (1939), who described the rodent Cittelus tridencenlineatus as having a hemochorial placenta without lobes, should be underscored.

Emphasis should be given to the fact that the definitive placenta of this animal group is the result of the interaction between the chorionic and the allantois membranes, giving origin to the chorioallantoic placenta, and corroborating with findings in the literature (Tibbits and Hillemann, 1959; Oduor-Okelo, 1984; Miglino et al., 2002; Oliveira et al., 2006; Mess, 2007a; Mess, 2007b; Oliveira et al, 2008; Kanashiro et al., 2009; Oliveira et al., 2012).

The placental barrier may be defined as the space between the maternal and fetal blood and the barrier is as great as the number of elements that divide maternal from fetal blood. According to Enders (1965), the maternal lacunas in rodents are separated from the maternal blood by a different number of components. When the maternal blood is separated from the fetal blood, the endothelium of the fetal capillary, the basal membrane and only one, two or three syncytiotrophoblast layers may be observed. The placentas are respectively called hemomono-, hemodi- and hemo-trichorial placentas due to the barrier formed between the two blood flows.

The limits that separate the maternal blood from the fetus in the placentas of the $K$. rupestris correspond to the hemomonochorial placentas defined by Enders (1965). In Kerodon rupestris, they are characterized by a single layer of syncytium trophoblast cells and the endothelial wall of the fetal capillary, separated by the basal membrane. Further, the syncytium trophoblast related to the maternal space is rich in microvillosities.
OLIVEIRA, M. F. et al.

Fenestrated capillaries in studies with placentation are important since they give the researcher a true idea of the numerous processes of exchanges between mother and fetus. Takata (1997) and Limongi and Ferro (2003) described fenestrations within the placental barrier of Calomys callouss and insisted that this fact was a weak function of the barrier. Fenestrations were not detected in K. rupestris as Oliveira et al. (2012) reported for the rodent Trichomys laurentinus, and thus differed from results by Takata (1997) and Limongi and Ferro (2003). It should be underlined that fenestrations have not been reported in studies on placentation in hystricomorph rodents. In fact, it may be a common feature to placentation models of the hemotrichorial type to improve exchange mechanisms since the placenta is composed of more maternal-fetal elements.

Since the type of placental barrier that separates the maternal blood from fetal blood has been identified, one must verify how syncytiotrophoblast cells behave when in contact with maternal blood to identify the transport mechanisms. The placental barrier has shown several syncytiotrophoblast microvillosities. They contained maternal blood and in their apexes a great amount of transport vesicles seemingly directed from maternal to fetal blood. Research by Oliveira et al. (2006) revealed villi and vesicles arranged in the apexes which suggested the transportation of substances between mother and fetus, similar to that in rodents in current analysis.

The hemochorial model of the placental barrier in rodents also revealed several and different subtypes. Kaufmann (1981) in studies on Cavia porcellus; Dantzer et al. (1988) on Chinchilla lanigera and Cavia porcellus; Kertschanska et al. (1997) on Octodon degus; Oduor-Okelo (1984) on Thryonomys shinderianus; Bonatelli et al. (2005) on Agouti paca; Mess (2007a) on the African rodent Petromus typicus and Oliveira et al. (2008) on Galea spixii, described the placental barrier as hemomonochorial, by which maternal blood is separated from fetal blood only by the wall of the fetal capillary basement membrane by a single syncytiotrophoblast layer, similar to that in the Kerodon rupestris, but different from reports by Enders and Welsh (1993) and Wislocki and Dempsey (1955) in Rattus sp. in which the placental barrier featured a hemotrichorial placenta. According to some authors (King, 1992; Bosco, 1997; Kertschanska et al., 97; Mess, 2003; Bosco et al., 2007), the inter-hematic barrier has a cell and a syncytium layer in the early stages of pregnancy; however, at advanced stages, the barrier diminishes 
and is merely formed by a simple or by a very thin syncytiotrophoblast layer.

In comparative studies on the thin layer of trophoblast in hemochorial placentas, Enders (1965) registered three layers of trophoblast which form the placental barrier of Mus musculus and Mesocricetus auratus. According to the author, the trophoblast in former hemotrichorial animals has a labyrinth organization with an external cell layer, a middle layer and an internal syncytium layer. Animals with a hemodichorial barrier have an external syncytium layer, whereas the internal one has cell limitations; the trophoblast layer was syncytial in animals with monochorial barrier, lacking any cell limitations, containing microvillae on the surface in contact with the maternal lacunae and with the fetal capillaries. The above is very similar to the monochorial placenta of $K$. rupestris, although the animal is a hystricomorph rodent. In their studies on the inter-hematic barrier of the rodent Ctenodactylus gundi, Mess and Carter (2009) reported that the barrier is formed by a single syncytiotrophoblast layer, albeit in groups of cytotrophoblasts in other regions.

As mentioned above, placentas are classified by hemomono-, hemodi- and hemotrichorial placental barriers. This classification is the result of verification obtained by transmission electron microscopy, where there are one, two or three interposing layers of trophoblast along with the endothelium of the fetal capillary and basement membrane to the fetal and maternal blood. In Cavidae, such as Octodon degus, Hydrochaeris hydrochaeris and Trichomys laurentinus, Mess (2007b), Kanashiro et al. (2009) and Oliveira et al. (2012), respectively, reported found that the barrier, beyond the capillary endothelium and the basal membrane, was constituted by a single layer of syncytial trophoblast. These features were also registered in $K$. rupestris which makes its maternalfetal barrier similar to that of the afore-mentioned rodents. This type of barrier differs from that described by Fisher (1971) who studied Castor canadensis, and still from that described by Carter (2007) and Furukawa et al. (2011) in mice and rats, since these species have, respectively, a di- and trichorial maternal-fetal barrier.

Maternal lacunae were identified in the subplacental region, on one side, limited by cellular cells and, on the other side, by syncytial cells, with microvillosities. Kanashiro et al. (2009) registered that this region in Hydrochaeris hydrochaeris contained the syncytiotrophoblast with microvilli in contact with the maternal blood and cytotrophoblast as a more internal layer. According to King (1982), the labyrinth and hemomonochorial conditions are characteristics of cavy-morph rodents, represented by cavies, degus and chinchilla. It certainly corresponds with a phylogenetic trait of the group, already discussed by Amoroso (1959), Carter (2001), Hillemann and Gaynor (1961) and Mossman (1987).

\section{CONCLUSIONS}

The shape of the placenta of $K$. rupestris is discoid and is the result of the allantois interaction with the chorium (chorioallantoic placenta).

It is lobed, with its maternal-fetal barrier made of three distinct elements: the wall of the fetal capillary, the basal membrane and a single syncytiotrophoblast layer separating the maternal from the fetal blood.

The placenta is thus hemochorial, subtype hemomonchorial, or rather, featuring a behavior similar to that reported for hystricomorph rodents.

RESUMO: A placenta dos roedores, de uma forma geral, é do tipo corioalantóidea, discoidal e hemocorial, características que se assemelham aos processos de placentação em humanos, o que torna esta ordem um interessante modelo experimental para a compreensão da placentação, da barreira placentária e os mecanismos fisiológicos envolvidos nas trocas materno-fetais. Neste aspecto, sabendo que o Kerodon rupestris pode ser utilizado como modelo placentário, objetivou-se caracterizar ultraestruturalmente a barreira placentária deste roedor. No experimento utilizaram-se três placentas provenientes de fêmeas de mocó no terço médio e duas no terço final da gestação obtidas no Centro de Multiplicação de Animais Silvestres da Universidade Federal Rural do Semi-Árido (CEMAS/UFERSA), Mossoró-RN, Brasil. Amostras com cerca de $1,0 \mathrm{~cm}$ foram coletadas e fixadas em solução de paraformoldeído em tampão fostafo $0,1 \mathrm{M}$, $\mathrm{pH} 7,4 \mathrm{a} 4^{\circ} \mathrm{C}$, enquanto fragmentos de $0,5 \mathrm{~mm}^{2}$ foram fixadas em solução de glutaraldeído a $2,5 \%$, tamponado com fosfato de sódio a 0,1 M, pH 7,4, e depois de processadas foram analisados no microscópio de luz e eletrônico de transmissão, respectivamente. A placenta do mocó apresentou-se quanto à forma como sendo do tipo discoidal. Além disto, resultou da interação entre o córion e o alantóide, fato que foi classificada como sendo um modelo de placenta corioalantoídea. Macro e microscopicamente era constituída de lóbulos predominantemente formados por capilares fetais que se interpunham na sua grande maioria às lacunas ou espaços maternos. O espaço inter hemático ou barreira materno-fetal da placenta de mocós é constituído por três elementos distintos representados pela parede do capilar fetal, a membrana basal e uma única camada de células trofoblásticas de natureza sincicial ou sinciciotrofoblasto propriamente dito, que separa o sangue 
materno do sangue fetal e ao mesmo tempo corresponde o meio pelo qual se processam todas as trocas metabólicas entre mãe e feto. Tais características são típicas de placentas denominadas hemocoriais e que pelo fato da barreira conter apenas uma camada de sinciciotrofoblasto é classificada como do subtipo hemomonocorial, comportamento semelhante ao relatado em roedores histricomorfos, como a cutia, a paca, a capivara e o preá.

PALAVRAS-CHAVE: Modelo animal. Hemocorial. Kerodon rupestris. Placenta. Roedor.

\section{REFERENCES}

ADRIAN, O.; SACHSER, N. Diversity of social and mating systems in cavies: a review. J. Mammal, Lawrence, v. 92, n. 1, p. 39-53, 2011. http://dx.doi.org/10.1644/09-MAMM-S-405.1

ABRAHAMSOHN, P. A.; ZORN, T. M. T. Implantation and Decidualization in Rodents. J. Exp. Zool., Texas, v. 266, n. 6, p. 603-628, 1993.

AMOROSO, E. C. Structural and funcional aspects of the placenta. Comparative Anatony of the placentas. Ann. N. Y. Acad. Sci., New York, v. 75, p. 855-872, 1959.

BONATELLI, M.; CARTER, A. M.; MACHADO, M. R. F.; OLIVEIRA, M. F.; LIMA, M. C.;

MIGLINO, M. A. Placentation in the paca (Agouti paca L). Reprod. Biol. Endocrinol., London, v. 3, p. 9, 2005.

BOSCO, C. Ultrastructure of the degu term placental barrier (Octodon degus): a labyrinthine hemomonochorial placental model. Med. Sci. Res., Gujarat, v. 25, p. 15-18, 1997.

BOSCO, C.; BUFFET, C.; BELLO, M. A.; RODRIGO, R.; GUTIERREZ, M.; GARCOA, G. Placentation in the degu (Octodon degus): analogies with extrasubplacental trophoblast and human pregnancies. Comp.

Biochem. Physiol. A. Mol. Integr. Physiol., Manitoba, v. 146, n. 4, p. 475-485, 2007.

BROLIO, N. P.; AMBRÓSIO, C. E.; FRANCIOLLI, A. R.; MORINI, A. C.; GUERRA, R. R.; MIGLINO, M. A. A barreira placentária e sua função de transferência nutricional. Rev. Bras. Reprod. Anim., Belo Horizonte, v. 34 , n. 4 , p. 222-232, 2010.

CARTER, A. M. Evolution of the placenta and fetal membranes seen in the light of molecular phylogenetics. Placenta, Eastbourne, v. 22, n. 10, p. 800-807, 2001. http://dx.doi.org/10.1053/plac.2001.0739

CARTER, A. M. Animal models of human placentation - a review. Placenta, Eastbourne, v.28, p.41-47, 2007. http://dx.doi.org/10.1016/j.placenta.2006.11.002

DANTZER, V.; LEISER, R.; KAUFMANN, P. Comparative morphological aspects of placental vascularization. Trophobl. Res., Cambridge, v. 3, p. 235-260, 1988. http://dx.doi.org/10.1007/978-1-46158109-3_17

ENDERS, A. C. A. Comparative study of the fine structure of the trophoblast in several hemochorial placentas. Am. J. anatomy, Washington, v. 116, p. 29-68, 1965.

ENDERS, E. A. C.; WELSH, A. O. Structural interactions of trophoblast and uterus during hemochorial placenta formation. J. Exp. Zool., Texas, v. 266, n. 6, p. 578-587, 1993.

FERREIRA, G. J. B. C.; OLIVEIRA, M. F.; CARVALHO, A. F.; MIGLINO, M. A.; AMBRÓSIO, C. E.; MARTINS, D. S.; MARTINS, J. F. P.; Morfologia da placenta do ratão do banhado (Myocastor coypus Molina, 1782). Rev. Bras. Reprod. Anim., Belo Horizonte, v. 26, p. 107-109, 2001.

FISCHER, T. V. Placentation in the American beaver (Castor canadensis). Am. J. anatomy, Washington, v. 131, n. 2, p. 159-184, 1971. 
FURUKAWA, S.; HAYASHI, S.; USUDA, K.; ABE, M.; HAGIO, S.; OGAWA, I. Toxicological pathology in the rat placenta. J. Toxicol. Pathol., Nagoya, v. 24, n. 2, p. 95-111, 2011.

GRAÇA-PIRES, A. Aspects of the placental vasculaization in the rabbit female, (Oryctolagus cuniculus) when gestation occurs under induced anemia condictions. Braz. J. Morphol. Anim. Sci., São Paulo, v. 15, p. 85-93, 1998.

HILLEMANN, H. H.; GAYNOR, A. I. The definitive architeture of the placenta of nutria, Myocastor coypus (MOLINA). Am. J. Anatomy, Washington, v. 109, n. 3, p, 299-317, 1961.

KANASHIRO, C.; SANTOS, T. C.; MIGLINO, M. A.; MESS, A. M.; CARTER, A. M.; Growth and development of the placenta in the capybara (Hydrochaeris hydrochaeris). Reprod. Biol. Endocrinol., London, v. 7, p. 57, 2009.

KAUFMANN, P. Eletron Microscopy of the Guinea-pig placental membranes. Placenta, Eastbourne, v. 2, p. 3$10,1981$.

KERTSCHANSKA, S.; SCHRÖDER, H.; KAUFMANN, P. The Ultrastructure of the trophoblastic layer of the degu (Octodon degus) Placenta: a re-evaluation of the "Channel Problem". Placenta, Eastbourne, v. 18, n. 2-3, p, 219-225, 1997.

KING, B. F. Comparative Anatomy of the Placental Barrier. Bibliot. Anat., Basel, v. 22, p. 13-28, 1982.

KING, B. F. Ultrastructural evidence for transtrophoblastic channels in the hemomonochorial placenta of the degu (Octodon degus). Placenta, Eastbourne, v. 13, p. 35-41, 1992. http://dx.doi.org/10.1016/0143-

4004(92)90005-E

LEISER, R.; KAUFMANN, P. Placental structure: in comparative aspect. Experimental Clinical

Endocrinology, v. 102, n. 3, p. 122-134, 1994.

http://dx.doi.org/10.1055/s-0029-1211275

LIMONGI, J. E.; FERRO, E. A. V.; Barreira placentária de Calomys callosus (Rodentia, Crcetidade). Biosci. J., Uberlandia, v. 19, n. 3, p. 89-94, 2003.

MESS, A. Evolutionary transformations of chorioallantoic placental characters in Rodentia with special reference to hystricognath species. J. Exp. Zool. A. Comp. Exp. Biol., Texas, v. 299, n. 1, p. 87-94, 2003.

MESS, A. Chorioallantoic and Yolk Sac Placentation in the Dassie Rat Petromus typicus and its Significance for the Evolution of Hystricognath Rodents. Placenta, Eastbourne, v. 28, n. 11-12, p. 1229-1233, 2007 a. http://dx.doi.org/10.1016/j.placenta.2007.05.005

MESS, A. Development of the Chorioallantoic Placenta in Octodon degus-A Model for Growth Processes in Caviomorph Rodents. J. Exp. Zool. (Mol. Dev. Evol.), Texas, v. 308, n. 4, p, 371-383, 2007 b.

MESS, A. M.; CARTER, A. M. Evolution of the Interhaemal Barrier in the Placenta of Rodents. Placenta, Eastbourne, v. 30, n. 10, p. 914-918, 2009. http://dx.doi.org/10.1016/j.placenta.2009.07.008

MIGLINO, M. A.; CARTER. A. M.; FERRAZ. R. H. S.; MACHADO, M. R. F. Placentation in the Capybara (Hydrochaerus hydrochaeris), Agouti (Dasyprocta aguti) and Paca (Agouti paca). Placenta, Eastbourne, v. 23, n. 5, p. 416-428, 2002. http://dx.doi.org/10.1053/plac.2002.0806

MIGLINO, M. A.; CARTER, A. M.; AMBROSIO, C. E.; OLIVEIRA, M. F.; FERRAZ, R. H. S.; RODRIGUES, R. F.; SANTOS, T.C. Vascular Organization of the Hystricomorph Placenta: a Comparative Study in the Agouti, Capybara, Guinea Pig, Paca and Rock Cavy. Placenta, Eastbourne, v. 25, n. 5, p. 438-448, 2004. http://dx.doi.org/10.1016/j.placenta.2003.11.002 
MOSSMAN, H. W. The rabbit placenta and problem of placental transmission. Am. J. Anatomy, Washington, v. 37, n. 3, p. 433-497, 1926.

MOSSMAN, H. W. Comparative morphogenesis of fetal membranes and accessory uterine structures. Contrib. Embryol. Carneg. Inst., Washington, v. 26, n. 1, p. 126-146, 1937.

MOSSMAN, H. W. Vertebrate fetal membranes: Comparative ontogeny and morphology; evolution; phylogenetic significance: basic functions; research opportunities. New Brunswick: Rutgers University Press. 1987. 400p.

MOSSMAN, H. W.; WEISFELDT, L. A. The fetal membranes of a primitive rodent, the trirteen-striped ground squirrel. Am. J. Anatomy, Washington, v. 64, n. 1, p. 59-109, 1939.

ODUOR-OKELO, D. An electron microscopic study of the chorion-allantoic placenta and the subplacenta of the cane rat (Thryonomys shinderianus Termminck). Placenta, Eastbourne,v. 5, p. 433-442, 1984. http://dx.doi.org/10.1016/S0143-4004(84)80024-7

OliveirA, M. F.; MIGlino, M. A. AlBUQUERQUE, J. F. G.; CARVALHO, M. A. M.; ASSIS NETO, A. C. Aspectos anatômicos do útero, placenta, feto e cordão umbilical de mocós, Kerodon rupestris (Wied 1820) criados em cativeiro. Rev. Bras. Reprod. Anim., São Paulo, v. 25, p. 171-173, 2001. http://dx.doi.org/10.1016/j.placenta.2004.11.012

OLIVEIRA, M. F.; CARTER, A. M.; BONATELLI, M.; AMBROSIO, C. E.; MIGLINO, M. A. Placentation in the rock cavy, Kerodon ruprestris (Wied). Placenta, Eastbourne, v. 27, n. 1, p. 87-97, 2006.

OLIVEIRA, M. F.; MESS, A.; AMBRÓSIO, C. E.; DANTAS, C. A. G.; FAVARON, P.O.; MIGLINO, M. A. Chorioallantoic placentation in Galea spixii (Rodentia, Caviomorpha, Caviidae). Reprod. Biol. Endocrinol., London, v. 6, p. 39, 2008.

OLIVEIRA, G. B.; ALBUQUERQUE, J. F. G.; RODRIGUES, M. N.; PAIVA, A. L. C.; MOURA, C. E. B.; MIGLINO, M. A.; OLIVEIRA, M. F. Origem e distribuição do nervo femoral do mocó, Kerodon rupestris (Cavidae). Pesq. Vet. Bras., Rio de Janeiro, v.31, n. 1, p. 84-88, 2011.

http://dx.doi.org/10.1590/S0100-736X2011001300014.

OLIVEIRA, M. F.; FAVARON, P. O.; AMBRÓSIO, C. E.; MIGLINO, M. A.; MESS, A.M. Chorioallantoic and yolk sac placentation in Thrichomys laurentinus (Echimyidae) and the evolution of hystricognath rodents. J. Exp. Zool. (Mol. Dev. Evol.), Texas, v. 318, n. 1, p. 13-25, 2012.

OLIVEIRA, M. F.; OLIVEIRA, G. B.; RODRIGUES, M. N.; BEZERRA, F. V. F.; COELHO, W. A. C.; ASSIS NETO, A. C.; SILVA, A. R.; MIGLINO, M. A. Correlação entre o peso, comprimento e anexos fetais de mocós (Kerodon rupestris Wied, 1820). Braz. J. Vet. Res. Anim. Sci., São Paulo, v. 51, n. 3, p. 204-211, 2014.

PIJNENBORG, R.; BLAND, J. M.; ROBERTSON, W. B.; DIXON, G.; BROSENS, I. The pattern of interstitial trophoblastic invasion of the myometrium in early human pregnancy. Placenta, Eastbourne, v. 2 , n. 4, p. 305-316. 1981.

PINHEIRO, M. J. P.; ANDRADE, S. A.; CUNHA, J. N. Preservação e exploração de animais silvestres nativos: preá, cutia e mocó. Caatinga, Mossoró, v. 6, p. 28-49, 1989.

QUEIROZ, P. V. S.; MOURA, C. E. B.; LUCENA, J. A.; OLIVEIRA, M. F.; ALBUQUERQUE, J. F. G. Artérias mesentéricas cranial e caudal em mocós Kerodon rupestris (Wied, 1820). Pesq. Vet. Bras., Rio de Janeiro, v. 31, n. 7, p. 623-626, 2011. 
RODRIGUES, R. F. A.; MIGLINO, M. A.; FERRAZ, R. H. S.; MORAIS-PINTO, L. Placentação em cutias (Dasyprocta aguti, CARLETON, MD): aspectos morfológicos. Braz. J. Vet. Res. Anim. Sci., São Paulo, v. 40, n. 2, p. 133-137, 2003.

RODRIGUES, M. N.; OLIVEIRA, G. B.; PAULA, V. V.; SILVA, A. R.; ASSIS NETO, A. C.; MIGLINO, M. A.; OLIVEIRA, M. F. Microscopy of the umbilical cord of rock cavies - Kerodon rupestris Wied, 1820 (Rodenta, Caviidae). Microsc. Res. Tech., Malden, v. 76, p. 419-422, 2013.

SCHLAFKE, S.; ENDERS, A. C. Cellular basis of interaction between trophoblast and uterus implantation. Biol. Reprod., New York, v. 12, p. 41-65, 1975.

TAKATA, K.; FUJIKURA, K.; SHIN, B. C. Ultrastructure of the rodent placental labyrinth: a site of barrier and transport. J. Reprod. Dev., Tóquio, v. 43, n. 1, p. 1-17, 1997.

THOMAZ, J. M.; CARVALHO, A. F.; MIGLINO, M. A.; MANÇANARES, C. A. F.; AMBRÓSIO, C. E.; OLIVEIRA, M. F. Caracterização morfológica dos dentes de mocó Kerodon rupestris: Mammalia: Rodentia. Braz. J. Vet. Res. Ani. Sci., São Paulo, v. 43, n. 5, 702-707, 2006.

TIBBITS, F. D.; HILLEMANN, H. H. The development and histology of the chinchilla placenta. J. Morphol., Malden, v. 105, p. 317-366, 1959.

TOLOSA, E. M. C.; RODRIGUES, C. J.; BEHEMER, A. O.; FREITAS NETO, A. G. Manual de técnicas normal e patológica. 2. ed. São Paulo: Manole. 2003. 341p.

WELSH, A. O.; ENDERS, A. C. Chorioallantoic placenta formation in the rat. II. Angiogenesis and maternal blood circulation in the mesometrial region of the implantation chamber prios to placenta formation. Am. J. Anatomy, Washington, v. 192, p. 347-365, 1991.

WISLOCKI, G. B.; DEMPSEY, E. W. Electron Microscopy of the placenta of the rat. Anat. Rec., Malden, v. 123, p. 33-64, 1955.

ZOGNO, M. A.; MIGLINO, M. A.; OLIVEIRA, M. F. Análise bioquímica dos líquidos fetais e citologia do fluido amniótico da fêmea de mocó (Kerodon rupestris). Braz. J. vet. Res. Anim. Sci., São Paulo, v. 41, n. 4, p. 226-235, 2004. 